\title{
Analisis Model Pengaruh Penyebab Terjadinya Waste Terhadap Peningkatan Biaya Konstruksi Gedung Bertingkat Rendah di Jakarta
}

\author{
Melchior Awanaman Ampim Suarliak ${ }^{1}$, Agus Suroso \\ Program Studi Megister Teknik Sipil, Universitas Mercu Buana, Jakarta ${ }^{1}$ \\ Koresponden*, Email: melchiorsuarliaktanimbar@gmail.com
}

\begin{tabular}{lc}
\hline & Info Artikel \\
\hline Diajukan & 25 Juni 2021 \\
Diperbaiki & 13 September 2021 \\
Disetujui & 13 September 202
\end{tabular}

\begin{abstract}
The cause of waste is the increase in costs incurred by the contractor so that they experience losses from excess material or wasted on construction projects. The purpose of this study is to analyze the influence model of the causes of waste to increase the cost of low-rise building construction in Jakarta. This research was collected from 14 (fourteen) different projects with a total of 84 respondents. The sampling technique used one of the techniques that became the choice of determining the sample, namely the probability random sampling technique, while the sample selection was selected by a simple random sampling procedure while the most dominant variable affecting the increase in construction costs is the formwork work variable. The increase in construction costs was obtained from the indicator that had the highest score, namely the formwork work variable for the X1.4 indicator with a percentage of $0.94 \%$ and the formwork demolition work for the X4.4 indicator with a percentage of $0.97 \%$, namely "Supervision of formwork installation is less intensive" and

"Incorrect demolition method" with a total score of 341 and an average of 4,059 with a score in the very good category.
\end{abstract}

Keywords: cause of waste, construction cost, low-rise building

\begin{abstract}
Abstrak
Penyebab terjadinya waste terhadap peningkatan biaya yang dikeluarkan oleh pihak kontraktor sehingga mengalami kerugian dari material yang berlebih atau pun terbuang pada proyek konstruksi. Tujuan dari penelitian ini yaitu untuk menganalisis model pengaruh penyebab terjadinya waste terhadap peningkatan biaya konstruksi gedung bertingkat rendah di Jakarta. Penelitian ini dikumpulkan dari 14 (empat belas) proyek yang berbeda dengan jumlah terkumpul dari 84 responden. Teknik pengambilan sampel dengan menggunakan teknik probabilitas random sampling, sedangkan untuk pemilihan sampel menggunakan simple random sampling. Variabel bekisting, pembesian, pengecoran dan pembongkaran bekisting berpengaruh terhadap peningkatan biaya konstruksi, sedangkan variabel yang paling dominan mempengaruhi peningkatan biaya konstruksi adalah variabel pekerjaan bekisting dan pekerjaan pembongkaran bekisting. Peningkatan biaya konstruksi diperoleh dari indikator yang memiliki skor tertinggi yaitu pada Variabel pekerjaan bekisting untuk indikator X1.4 dengan persentase $0,94 \%$ dan Varibel pekerjaan pembongkaran bekisting untuk indikator X4.4 dengan persentase $0,97 \%$ yaitu "Pengawasan pemasangan bekisting kurang insentif" dan "Metode pembongkaran yang kurang tepat" dengan skor total 341 dan rata-rata 4.059 dengan nilai persentase dalam kategori yang baik sekali.
\end{abstract}

kus pada bangunan dengan jumlah lantai 2 sampai dengan 4 lantai.

Bangsa ini memerlukan bangunan infrastruktur yang sangat banyak. Salah satu infrastruktur tersebut adalah bangunan gedung. Gedung yang merupakan salah satu bangunan konstruksi memiliki beberapa bagian pekerjaan seperti pekerjaan struktur, arsitektur serta mekanikal elektrikal dan plumbing (MEP). Sehingga pada penelitian ini berfokus pada pekerjaan struktur yaitu merupakan pekerjaan awal yang memiliki bagian-bagian yang membentuk sebuah bangunan. Pekerjaan ini memiliki beberapa item pekerjaan seperti pekerjaan bekisting, pekerjaan pembesian, pekerjaan ataupun bertingkat tinggi. Namun pada penelitian ini berfo- 
pengecoran dan pembongkaran bekisting yang memiliki metode masing-masing dalam pekerjaannya.

Pada penelitian sebelumnya waste material dapat diartikan sebagai material yang tidak diinginkan atau tidak memiliki nilai jual dan tidak dapat difungsikan sebagai mana material lainnya atau pemakaian. Analisis yang digunakan analisis kuantitaf untuk mengetahui jenis material yang terbesar dan kerugian dalam pekerjaan beton dihitung dengan metode regresi dibantu dengan program SPSS untuk mendapatkan besar kerugian yang terjadi pada konstruksi pekerjaan beton. Data yang diperoleh menghasilkan sisa material dengan jumlah paling besar pada konstruksi beton adalah $7.05 \%$ untuk proyek gedung bertingkat rendah di Jakarta dan sekitarnya dan kerugian (\%) yang memilik regresi seperti berikut $\mathrm{Y}=-1.640+0.669 \mathrm{X} 1+0.481 \mathrm{X} 2+$ 0.098 X3 [1]. Dengan pertimbangan nilai waste yang cukup besar.

Dalam setiap proyek yang dilakukan sudah menjadi hal wajar ketika terjadi sisa material pada proyek tersebut, mengingat material merupakan hal yang harus ada pada setiap kegiatan pembangunan yang dilakukan. Sehingga dengan adanya sisa material pada kegiatan pembangunan tentu akan menyebabkan biaya pembangunan akan semakin besar.

Sisa material yang dihasilkan dari kegiatan pembangunan akan berdampak pada semakin besarnya biaya yang dikeluarkan oleh kontraktor, dengan bertambahnya biaya pembangunan pada setiap proyek tentu akan menjadikan proyek tersebut berpotensi mengalami kerugian, terlebih beberapa material akan terbuang sia-sia. Pada penelitian yang telah dilakukan pada waktu yang telah lalu didapatkan hasil bahwa akibat yang ditimbulkan dari tidak efisiennya biaya yang dikeluarkan oleh kontraktor disebabkan oleh kurangnya perhatian pada menerapkan sistem waste pada setiap manajemen dalam proyek yang dikerjakan, sehingga besarnya persentase yang dihasilkan oleh sisa material pada proyek yang dikerjakan berkisar antara 40 sampai $60 \%$ dari total biaya keseluruhan yang dikeluarkan oleh kontraktor [2]. Sedangkan persentase besarnya sisa material yang dihasilkan dari seluruh proyek pembangunan gedung berkisar di angka 3 sampai 13,5\% [3].

Mengacu pada penelitian yang telah dilakukan oleh Aulia yang menerapkan metode pareto [4], setelah melalui kegiatan rencana penelitian dan dan menjalankan seluruh rangkaian kegiatan riset sesuai dengan pedoman penulisan karya ilmiah, didapatkan hasil bahwa terdapat tiga jenis material yang mayoritas menjadi sisa pada setiap proyek yang dikerjakan. Ketiga material tersebut yang pertama adalah tiang pancang yang kedua tulangan D16 dan yang terakhir adalah tulangan D22. Setelah dilakukan analisis data menggunakan metode fishbone didapatkan hasil bahwa salah satu sebab yang menjadikan tiang pancang sering tersisa pada setiap proyek, diakibatkan oleh kondisi tiang pancang yang kurang baik sehingga tidak bisa di digunakan dalam proyek yang dikerjakan. Tiang pancang yang mengalami pengurangan kualitas diakibatkan oleh proses loading unloading yang tidak mendapatkan perhatian khusus.

Pada penelitian lainnya yang mengkaji tentang penyebab terjadinya material tersisa ketika melakukan proyek pembangunan [5]. Didapatkan hasil bahwa ada 2 material yang sering tersisa ketika melakukan proyek pembangunan. Pertama adalah material baja tulangan sedangkan yang kedua adalah tiang pancang. Setelah dilakukan kajian lapangan dan mendokumentasikan seluruh kegiatan penelitian yang dilakukan analisis secara mendalam, didapatkan berbagai faktor yang menjadikan material baja tulangan sering tersisa dalam proyek pembangunan. Faktor tersebut paling tidak ada delapan, pertama ialah peralatan yang sudah mengalami penurunan fungsi, kedua pemotongan yang Dipaksakan mengikuti desain struktur bangunan, ketiga pekerja tidak meneliti ulang terhadap pekerjaan yang dilakukan, keempat terjadinya konsleting listrik, kelima kurangnya pengalaman yang dimiliki oleh pekerja, keenam tidak disiplinnya mandor, ketujuh terjadinya perubahan desain struktur secara mendadak, dan yang terakhir tidak adanya koordinasi yang baik. Sedangkan penyebab yang menjadikan tiang pancang sering tersisa dalam proyek pembangunan ialah ketidaktelitian dalam proses pemeriksaan material ketika tiang pancang didistribusikan di lokasi proyek pembangunan.

Sisa material Mengacu pada penelitian terdahulu yang dilakukan oleh Hartono, mendapatkan hasil bahwa terdapat dua jenis material yang sering tersisa dalam proyek pembangunan. Pertama ialah bata merah dengan sisa material terbesar dengan jumlah $21,84 \%$, kedua ialah material keramik dengan ukuran 40 x 40, dengan sisa material memiliki persentase sisa material berjumlah 21,07\%. Bata merah menjadi penyumbang terbesar dalam sisa material yang digunakan dalam proyek pembangunan, dikarenakan material tersebut merupakan material tambahan dan bukan merupakan material utama [6].

Data hasil Zulkibli, dkk [7] menunjukkan bahwa: Persentase sisa biaya material terbesar yang diteliti selama pelaksanaan proyek berasal dari material baja beton senilai $\mathrm{Rp}$ 5.4838.000,00 total respon kuesioner setiap jenis material limbah yang diteliti merupakan limbah material pasir terbesar $19,68 \%$, persentase yang dihasilkan oleh sisa material ketika mengerjakan proyek sebesar $4,9 \%$ dari total seluruh biaya yang dikeluarkan pada material limbah, sedangkan jika dibandingkan dengan seluruh biaya pada proyek ter- 
sebut. Sisa biaya material memiliki persentase $1,87 \%$. Sedangkan jika dibandingkan dengan besarnya biaya yang dikeluarkan ketika kegiatan pengisian kuesioner di lapangan dan besarnya biaya yang dikeluarkan pada sebab terjadinya pengeluaran limbah terbesar [X3] memiliki faktor yang dapat menanggulangi hal tersebut sebesar $35,75 \%$. Selain itu upaya pengurangan limbah material di dalam tanah merupakan metode pengelolaan material yang baik.

Aspek manfaat antara lain sebagai bahan rujukan pihak pemberi tugas sehingga dapat mengetahui material apa yang sering terjadi sisa material (waste), sehingga dapat menggunakan anggaran sebaiknya. Sebagai bahan rujukan pihak pengawas sehingga dapat mengawasi sisa material (waste), terhadap penggunaan material bisa efektif. Sebagai bahan rujukan pihak kontraktor sehingga dapat menggunakan penelitian ini sebagai referensi pengendalian material, terhadap dampak sisa material yang tidak merugikan biaya anggaran.

\section{Pendahuluan}

Riset dilakukan di 14 (empat belas) proyek yang berbeda di jakarta. Setelah dilakukan observasi lapangan, diperoleh informasi mengenai jumlah sampel dari keseluruhan proyek tersebut ada 84 orang. Teknik pengambilan sampel dengan menggunakan teknik probabilitas random sampling. Sedangkan untuk pemilihan sampel menggunakan simple random sampling [8]. Kriteria yang dijadikan sebagai responden yaitu orang-orang yang berhubungan dengan penggunaan material pada pekerjaan pembangunan gedung bertingkat rendah seperti project manager, site manager, quantity surveyor, pengawas lapangan, logistik serta gudang. Berdasarkan riset terdahulu menyatakan bahwa populasi yang berjumlah kurang dari 100, maka akan semua menjadi sampel, maka dapat disimpulkan bahwa sampel dari penelitian ini berjumlah 84 orang responden.

Variabel dalam penelitian ini ada empat pokok dari sisa material pada pekerjaan struktur dari pekerjaan bekisting, pekerjaan pengecoran, pekerjaan pembesian dan pekerjaan pembongkaran bekisting terhadap peningkatan biaya. Desain dalam riset ini terdiri dari data primer dan data sekunder. Data primer adalah sumber informasi yang secara langsung memberikan informasi kepada otoritas informasi sedangkan data sekunder adalah sumber informasi yang tidak langsung memberikan informasi kepada pengumpul informasi. Sumber data pada riset yang akan dilakukan ini terdiri dari 2 (dua) yaitu:

1. Data Primer yang akan dilakukan yaitu riset metode survey, wawancara dan membagikan kuesioner kepada pihak yang terlibat dalam objek penelitian pembangunan gedung bertingkat rendah di Jakarta
2. Data Sekunder untuk riset metode survei diperoleh dari studi literatur diantaranya yaitu website, buku, jurnal riset terdahulu.

Metode survei yang dilakukan yaitu pengumpulan data riset dengan cara menyebarkan isi kuesioner kepada pihak project manager, site manager, quantity surveyor, pengawas lapangan, logistik serta gudang untuk mendapatkan informasi mengenai penyebab dan pengaruhnya terhadap biaya pada konstruksi gedung bertingkat rendah. Penyebaran daftar pertanyaan atau kuesioner dilakukan dengan mendatangi langsung pada proyek konstruksi pada beberapa proyek konstruksi di daerah khusus ibukota jakarta. Setelah observasi dilakukan, maka didapatkan sampel pada objek riset sebanyak 84 responden yang berada di 14 (empat belas) proyek yang sedang berjalan di 5 lokasi yang berbeda. Pertama ialah Jakarta Pusat, kedua Jakarta Timur, ketiga Jakarta Selatan, keempat Jakarta Barat dan yang terakhir Tangerang.

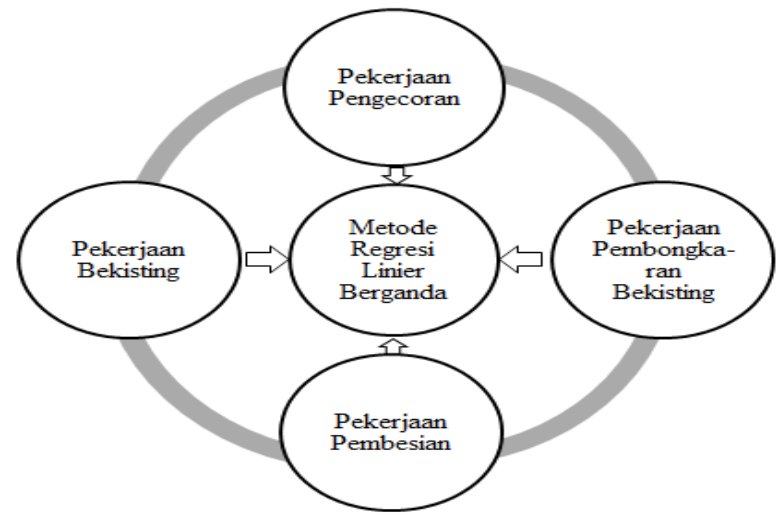

Gambar 1. Metode Analisis Data [2].

Metode analisis data riset ini mengunakan regresi liner berganda. Pengujian yang dijalankan dimulai dengan uji validasi, uji reliabilitas, uji asumsi klasik, kemudian uji regresi linier berganda, uji t, kemudian uji f. Apabila instrumen riset dinyatakan valid, dan reliabel langkahberikutnya yaitu melakukan, pengujian pada asumsi klasik. Pengujian asumsi klasik meliputi beberapa uji normalitas, multikolinearitas, heteroskedastisitas, dan autokorelasi. Setelah instrument riset dinyatakan sesuai dengan ketentuan selanjutnya yaitu melakukan uji, regresi linier berganda. Riset ini terdiri dari pengujian korelasi koefisien, dan determinasi koefisien. Untuk riset hipotesis dilakukan dengan uji t sebagai upaya untuk mengetahui berapa besar pengaruh yang dihasilkan oleh variabel dependen yang menerapkan seberapa besar variasi yang dihasilkan oleh variabel dependen. Selain itu uji t dilakukan untuk mengetahui seberapa besar nilai yang dihasilkan oleh uji f. 


\section{Hasil dan Pembahasan}

Keterbaruan (state of the art) pada riset ini yaitu membahas mengenai model pengaruh penyebab terjadi waste terhadap peningkatan biaya konstruksi gedung bertingkat rendah di Jakarta dengan dibantu menggunakan simulasi tools Microsoft Excel dan Statistical Package for the Social Sciences (SPSS)

Pada tahap pertama yaitu penyebaran kuesioner dilakukan dengan cara membagikan ke 5 (lima) pakar kemudian memberikan tanggapan beserta masukan terhadap 4 variabel penelitian dengan total jumlah 22 indikator yang diajukan dapat dilihat pada Tabel 1

Kemudian hasil persepsi validasi didapatkan beberapa indikator variabel yang dikeluarkan karena menurut para pakar kurang sesuai. Indikator tersebut yaitu: X.1.5, X.2.5, X.2.6, X.3.5, X.3.6, dan X4.5 sehingga terdiri 16 indikator variabel yang tersisa dapat dilanjutkan kuesioner kedua dilihat pada Tabel 2.

Riset selanjutnya penyebaran kuesioner kepada pihak yang ikut serta dalam pembangunan konstruksi gedung bertingkat rendah dengan jumlah responden 84 , didapatkan data bahwa usia terbanyak yang dimiliki oleh responden ialah berusia 31 sampai dengan 40 tahun dengan jumlah responden sebanyak 43 atau dengan persentase sebesar $(51,20 \%)$, sedangkan yang memiliki usia antara 40 sampai 50 tahun hanya berjumlah 1 responden atau dengan persentase sebesar $(1,9 \%)$, usia $40 \mathrm{~s} / \mathrm{d} 50$ tahun sebanyak 38 responden $45,23 \%$ ), sedangkan untuk usia $>50$ sebanyak 2 responden $(2,38 \%)$.

Jika melihat pada latar pendidikan yang dimiliki oleh responden, memiliki 4 kriteria yang berbeda yang pertama ialah responden yang berpendidikan S1 dengan jumlah paling sedikit sebanyak 5 responden atau dengan persentase $5,95 \%$, jumlah terbanyak ialah responden dengan pendidikan S1 sebanyak 47 atau dengan persentase 55,95\%, pendidikan D3 memiliki 19 responden atau dengan persentase $22,62 \%$,sedangkan yang terakhir ialah responden dengan pendidikan SMA atau yang sederajat dengan jumlah 13 atau dengan persentase $15,48 \%$. Mengacu pada lamanya pengalaman kerja yang dimiliki oleh responden.

Terdapat lima kriteria antara lain pertama ialah yang memiliki pengalaman kerja di bawah 5 tahun dengan jumlah paling sedikit yaitu 1 responden atau dengan persentase $1,19 \%$, kedua yang memiliki pengalaman kerja 5 sampai dengan 10 tahun memiliki 16 responden atau dengan persentase $19,05 \%$ responden, ketiga yang memiliki pengalaman kerja 10 sampai 15 tahun terdapat 26 responden atau dengan persentase $30,95 \%$, responden dengan pengalaman kerja terbanyak yaitu dengan rentan pengalaman 15 sampai dengan 20 tahun dengan jumlah responden 34 atau men- capai persentase $40,48 \%$, sedangkan terakhir yang memiliki pengalaman kerja di atas 20 tahun berjumlah 7 responden atau dengan persentase $8,33 \%$. Jika melihat pada jumlahnya proyek yang dipegang oleh responden.

Terdapat lima kriteria. Pertama ialah responden dengan jumlah proyek 5 sampai dengan 10 jumlah 14 atau dengan presentase $16,66 \%$ sedangkan kan responden dengan jumlah proyek 11 sampai 15 berjumlah 35 responden atau dengan persentase terbesar yaitu $41,67 \%$, responden dengan jumlah proyek 16 sampai 20 berjumlah 31 atau dengan presentase $36,90 \%$, responden dengan jumlah proyek di atas 20 sebanyak 4 atau dengan presentase $4,77 \%$, sedangkan responden yang memiliki proyek di bawah 5 tidak ada. Sedangkan jika berpedoman pada jabatan yang dimiliki oleh responden

Terdapat beberapa jenis jabatan. Jabatan tersebut sangat berhubungan dengan besarnya material yang tersisa ketika proyek pembangunan gedung. Dimana data memberikan informasi bahwa jabatan Project Manager sebanyak 14 atau dengan persentase X\%, Site Manager sebanyak 14 dengan persentase X\%, Quantity Surveyor sebanyak 14 dengan persentase $\mathrm{X} \%$, Pengawas Lapangan sebanyak 14 dengan persentase $\mathrm{X} \%$, Logistik sebanyak 14 dengan persentase $\mathrm{X} \%$, serta Gudang sebanyak 14 dengan presentase $\mathrm{X} \%$.

Melalui analisis statitistik deskriptif akan diperoleh gambaran sekilas mengenai indikator pengaruh sisa material yang memiliki skala tertinggi pada proyek yang dilihat dari skor total tertinggi pada masing-masing variabel. Hasil analisis deskriptif akan disajikan dalam masing-masing variabel. Berikut ini adalah tabulasi hasil analisis deskriptif variabel independen (X) dan variabel dependen (Y) untuk analisis model pengaruh sisa material terhadap peningkatan biaya konstruksi gedung bertingkat rendah di Jakarta. Berdasarkan resume riset dapat dilihat pada Tabel 3. Menjelaskan mengenai indikator yang memiliki skor tertinggi yaitu pada Variabel Pekerjaan Bekisting untuk indikator X1.4 dan Pekerjaan Pembongkaran Bekisting untuk indikator X4.4 yaitu "Pengawasan pemasangan bekisting kurang intensif" dan "Metode pembongkaran yang kurang tepat" dengan skor total 341 dan rata-rata 4.059, hal ini menyimpulkan bahwa berdasarkan analisis statistik deskriptif, pengaruh sisa material paling dominan yang menyebabkan terhadap peningkatan biaya konstruksi gedung bertingkat rendah di jakarta adalah pekerjaan bekisting dan pekerjaan pembongkaran bekisting.

\section{Uji Reliabilitas}

Pengujian reliabilitas instrumen variabel bekisting (X1), pembesian (X2), pengecoran (X3), pembongkaran bekisting (X4) dilakukan dengan SPSS Versi 21 menggunakan formula Cronbach Alpha, dengan ketentuan: 
a. Bila nilai koefisien reliabilitas $(r)>0,60$, maka instrumen variabel dinyatakan reliabel.

b. Bila nilai koefisien reliabilitas $(r)<0,60$. maka instrumen variabel dinyatakan kurang reliabel.

Tabel 1. Variabel Bebas (X)

\begin{tabular}{|c|c|c|}
\hline Variabel & & Indikator \\
\hline \multirow[t]{5}{*}{$\begin{array}{l}\text { Pekerjaan } \\
\text { Bekisting (X1) }\end{array}$} & $\mathrm{X} 1.1$ & $\begin{array}{l}\text { Kesalahan yang dilakukan pekerja } \\
\text { dalam pemotongan kayu }\end{array}$ \\
\hline & $\mathrm{X} 1.2$ & $\begin{array}{l}\text { Menggunakan material triplek de- } \\
\text { ngan kualitas rendah }\end{array}$ \\
\hline & $\mathrm{X} 1.3$ & $\begin{array}{l}\text { Pemotongan sisa bekisting bondek } \\
\text { tidak digunakan }\end{array}$ \\
\hline & $\mathrm{X} 1.4$ & $\begin{array}{l}\text { Pengawasan pemasangan bekisting } \\
\text { kurang intensif }\end{array}$ \\
\hline & $\mathrm{X} 1.5$ & $\begin{array}{l}\text { Kesalahan dalam meninterpretasikan } \\
\text { gambar dan spesifikasi }\end{array}$ \\
\hline \multicolumn{2}{|l|}{ Variabel } & Indikator \\
\hline \multirow[t]{6}{*}{$\begin{array}{l}\text { Pekerjaan } \\
\text { Pembesian (X2) }\end{array}$} & $\mathrm{X} 2.1$ & $\begin{array}{l}\text { Besi yang terlanjur terpotong tidak } \\
\text { sesuai ukuran }\end{array}$ \\
\hline & $\mathrm{X} 2.3$ & $\begin{array}{l}\text { Sisa pemotongan tidak dapat di gu- } \\
\text { nakan }\end{array}$ \\
\hline & $\mathrm{X} 2.3$ & $\begin{array}{l}\text { Metode pemasangan yang kurang te- } \\
\text { pat }\end{array}$ \\
\hline & $\mathrm{X} 2.4$ & $\begin{array}{l}\text { Material berkarat akibat terlalu lama } \\
\text { disimpan }\end{array}$ \\
\hline & $\mathrm{X} 2.5$ & Penyedian area pemotongan material \\
\hline & $\mathrm{X} 2.6$ & Membeli besi kelibihan pemakaian \\
\hline \multirow{7}{*}{$\begin{array}{l}\text { Variabel } \\
\text { Pekerjaan } \\
\text { Pengecoran } \\
\text { (X3) }\end{array}$} & & Indikator \\
\hline & $\mathrm{X} 3.1$ & $\begin{array}{l}\text { Semen, pasir dan kerikil tercecer, ter- } \\
\text { buang selama pembuatan adukan be- } \\
\text { ton }\end{array}$ \\
\hline & $\mathrm{X} 3.2$ & Kelebihan adukan beton dilapangan \\
\hline & $\mathrm{X} 3.3$ & $\begin{array}{l}\text { Ukuran batu split yang tidak sesuai } \\
\text { spesifikasi }\end{array}$ \\
\hline & $\mathrm{X} 3.4$ & $\begin{array}{l}\text { Tidak merencanakan menggunakan } \\
\text { material dengan baik }\end{array}$ \\
\hline & $\mathrm{X} 3.5$ & Cuaca yang buruk \\
\hline & X3.6 & $\begin{array}{l}\text { Kerikil yang tercecer dan tercampur } \\
\text { dengan material lain }\end{array}$ \\
\hline \multirow{6}{*}{$\begin{array}{l}\text { Variabel } \\
\text { Pekerjaan } \\
\text { Pembongkaran } \\
\text { Bekisting (X4) }\end{array}$} & & Indikator \\
\hline & $\mathrm{X} 4.1$ & $\begin{array}{l}\text { Material kayu dan triplek tidak awet } \\
\text { untuk dipakai berulang-ulang kali }\end{array}$ \\
\hline & $\mathrm{X} 4.2$ & $\begin{array}{l}\text { Sisa potongan bekisting bondek tidak } \\
\text { dapat di pakai lagi }\end{array}$ \\
\hline & $\mathrm{X} 4.3$ & $\begin{array}{l}\text { Paku dan kawat bendrat yang sudah } \\
\text { tidak bisa dipakai kembali karena } \\
\text { proses pemakaian }\end{array}$ \\
\hline & $\mathrm{X} 4.4$ & $\begin{array}{l}\text { Metode pembongkaran yang kurang } \\
\text { tepat }\end{array}$ \\
\hline & $\mathrm{X} 4.5$ & $\begin{array}{l}\text { Membuang atau melempar material } \\
\text { pembongkaran secara sengaja atau } \\
\text { tidak }\end{array}$ \\
\hline
\end{tabular}

Tabel 2. Variabel Valid dan Reliabel

\begin{tabular}{|c|c|c|}
\hline Variabel & & Indikator \\
\hline \multirow[t]{4}{*}{$\begin{array}{c}\text { Pekerjaan } \\
\text { Bekisting (X1) }\end{array}$} & X1.1 & $\begin{array}{l}\text { Kesalahan yang dilakukan pekerja } \\
\text { dalam pemotongan kayu }\end{array}$ \\
\hline & $\mathrm{X} 1.2$ & $\begin{array}{l}\text { Menggunakan material triplek } \\
\text { dengan kualitas rendah }\end{array}$ \\
\hline & $\mathrm{X} 1.3$ & $\begin{array}{l}\text { Pemotongan sisa bekisting bondek } \\
\text { tidak digunakan }\end{array}$ \\
\hline & X1.4 & $\begin{array}{l}\text { Pengawasan pemasangan bekisting } \\
\text { kurang intensif }\end{array}$ \\
\hline Variabel & & Indikator \\
\hline \multirow[t]{4}{*}{$\begin{array}{c}\text { Pekerjaan } \\
\text { Pembesian (X2) }\end{array}$} & $\mathrm{X} 2.1$ & $\begin{array}{l}\text { Besi yang terlanjur terpotong tidak } \\
\text { sesuai ukuran }\end{array}$ \\
\hline & $\mathrm{X} 2.3$ & $\begin{array}{l}\text { Sisa pemotongan tidak dapat di } \\
\text { gunakan }\end{array}$ \\
\hline & $\mathrm{X} 2.3$ & $\begin{array}{l}\text { Metode pemasangan yang kurang } \\
\text { tepat }\end{array}$ \\
\hline & $\mathrm{X} 2.4$ & $\begin{array}{l}\text { Material berkarat akibat terlalu } \\
\text { lama disimpan }\end{array}$ \\
\hline Variabel & & Indikator \\
\hline \multirow[t]{4}{*}{$\begin{array}{c}\text { Pekerjaan } \\
\text { Pengecoran (X3) }\end{array}$} & $\mathrm{X} 3.1$ & $\begin{array}{l}\text { Semen, pasir dan kerikil tercecer, } \\
\text { terbuang selama pembuatan adukan } \\
\text { beton }\end{array}$ \\
\hline & $\mathrm{X} 3.2$ & $\begin{array}{l}\text { Kelebihan adukan beton } \\
\text { dilapangan }\end{array}$ \\
\hline & $\mathrm{X} 3.3$ & $\begin{array}{l}\text { Ukuran batu split yang tidak sesuai } \\
\text { spesifikasi }\end{array}$ \\
\hline & X3.4 & $\begin{array}{l}\text { Tidak merencanakan menggunakan } \\
\text { material dengan baik }\end{array}$ \\
\hline Variabel & & Indikator \\
\hline \multirow[t]{4}{*}{$\begin{array}{c}\text { Pekerjaan } \\
\text { Pembongkaran } \\
\text { Bekisting (X4) }\end{array}$} & $\mathrm{X} 4.1$ & $\begin{array}{l}\text { Material kayu dan triplek tidak } \\
\text { awet untuk dipakai berulang-ulang } \\
\text { kali }\end{array}$ \\
\hline & $\mathrm{X} 4.2$ & $\begin{array}{l}\text { Sisa potongan bekisting bondek } \\
\text { tidak dapat di pakai lagi }\end{array}$ \\
\hline & $\mathrm{X} 4.3$ & $\begin{array}{l}\text { Paku dan kawat bendrat yang } \\
\text { sudah tidak bisa dipakai kembali } \\
\text { karena proses pemakaian }\end{array}$ \\
\hline & X4.4 & $\begin{array}{l}\text { Metode pembongkaran yang } \\
\text { kurang tepat }\end{array}$ \\
\hline
\end{tabular}

Pengujian reliabilitas, salah satunya yang dipakai adalah metode Cronbach's Alpha. Setelah diuji validitasnya maka item-item yang gugur dibuang dan item yang tidak gugur dimasukkan ke dalam uji reliabilitas. Maka yang akan dihitung ada sebanyak 16 indikator $(N$ of Item $=16)$. 
Tabel 4. Statistik Deskriptif Variabel X dan Y Descriptive Statistics

\begin{tabular}{cccccc}
\hline No & Variabel & $\begin{array}{c}\mathrm{r}- \\
\text { tabel }\end{array}$ & $\begin{array}{c}\text { Cronbach's } \\
\text { Alpa }\end{array}$ & $\begin{array}{c}\text { N of } \\
\text { Item }\end{array}$ & $\begin{array}{c}\text { Keterang } \\
\text { an }\end{array}$ \\
\hline 1 & $\begin{array}{l}\text { Pekerjaan } \\
\text { Bekisting }\end{array}$ & 0,214 & 0,719 & 4 & Reliabel \\
2 & $\begin{array}{l}\text { Pekerjaan } \\
\text { Pembesian }\end{array}$ & 0,214 & 0,757 & 4 & Reliabel \\
3 & $\begin{array}{l}\text { Pekerjaan } \\
\text { Pengecoran } \\
4\end{array}$ & 0,214 & 0,662 & 4 & Reliabel \\
& $\begin{array}{l}\text { Pekerjaan } \\
\text { Pembongkaran } \\
\text { Bekisting }\end{array}$ & 0,214 & 0,759 & 4 & Reliabel \\
\hline
\end{tabular}

Berdasarkan hasil perhitungan diperoleh bahwa semua variabel memiliki nilai koefisien reliabilitas (r) $>0,60$ dengan demikian semua variabel dapat dikatakan memiliki status yang reliabel.

\section{Uji Asumsi Klasik}

Uji multikolinearitas merupakan sebuah keadaan yang menggambarkan variabel $\mathrm{X}$ yang merupakan variabel bebas memiliki hubungan antara satu dengan yang lainnya. Persamaan regresi ganda didefinisikan sebagai persamaan yang terbebas dari unsur multikolinearitas yang dihasilkan dari variabel bebasnya. Dalam menentukan besarnya nilai yang dihasilkan oleh uji multikolinearitas menggunakan rumus VIF (Variance Inflation Factor),

Tabel 5. Uji Multikolinearitas (Coefficient Correlations)

\begin{tabular}{lcc}
\hline \multirow{2}{*}{\multicolumn{1}{c}{ Model }} & \multicolumn{2}{c}{ Collinearity Statistics } \\
\cline { 2 - 3 } & Tolerance & VIF \\
\hline Bekisting & .265 & 3.781 \\
Pembesian & .168 & 5.943 \\
Pengecoran & .187 & 5.348 \\
Pembongkaran Bekisting & .268 & 3.735 \\
\hline
\end{tabular}

Dari hasil riset maka dapat diketahui ada atau tidak terkait problem multikolinearitas dalam suatu variabel yang sedang peneliti lakukan riset. Arti dasar pengambilan keputusan adalah besaran VIF (Variance Inflation Factor) dan Tolerance. Pedoman model regresi yang bebas multikolinieritas adalah:

a. Mempunyai nilai VIF di bawah 10 .

b. Mempunyai angka tolerance di atas 0,10.

Dengan melihat hasil pada, Tabel 5 pada kolom VIF Variance Inflation Factor terlihat dari keempat variabel independen, angka menunjukkan hasil dibawah $10\left(\mathrm{X}_{1}=\right.$ $3,781, X_{2}=5,943, X_{3}=5,348$ dan $\left.X_{4}=3,735\right)$. Sama halnya pada kolom Tolerance terrlihat dari keempat variabel independen, angka menunjukkan hasilnya diatas 0,10 $\left(X_{1}=0,265, X_{2}=0,168, X_{4}=0,187\right.$ dan $\left.X_{4}=0,268\right)$. Maka dapat disimpulkan oleh untuk riset model regresi yang ada tidak ada problem multikolinearitas baik melalui jumlah besaran VIF ataupun banyaknya besaran korelasi antara variabel satu dengan yang lainnya.

Tujuan dari pengujian heterokedastisitas yaitu untuk melakukan pengujian pada suatu model regresi, terdapat aktivitas yang tidak sama antara dengan variabel dari residual melalui observasi satu ke yang lainnya. Uji heteroskedastisitas dari 4 variabel dengan menerapkan alat bantu program aplikasi SPSS versi 21 yang ditampilkan dalam bentuk grafik pada Gambar 2.

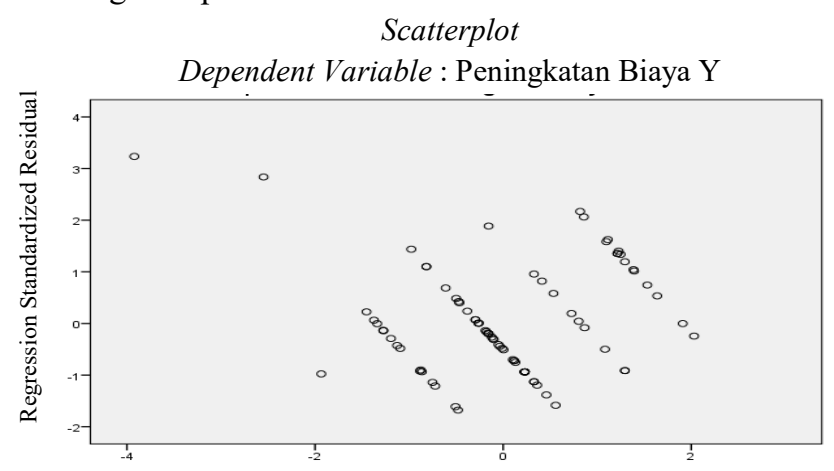

Gambar 2. Hasil Uji heterokedastisitas [2]

Setelah melihat hasil pada Gambar 2 yang berisi grafik maka terlihat ada beberapa titik yang tersebar secara acak, tidak dapat membentuk menjadi sebuah pola tertentu secara jelas dan penyebarannya terletak di atas atau di bawah angka 0 pada sumbu $\mathrm{Y}$ hasil ini dapat diartikan tidak mengalami heteroskedastisitas pada model regresi maka dapat dinyatakan layak untuk digunakan dalam memprediksi variabel peningkatan biaya konstruksi (Y). Berdasarkan masukan variabel bekisting (X1), pembesian (X2), pengecoran (X3), pembongkaran bekisting (X4).

\section{Analisis Persamaan Regresi Berganda}

Setelah mengetahui hasil riset penghitungan dan pengolahan data melalui aplikasi bantu SPSS, maka pembahasan selanjutnya terkait persamaan regresi berganda. Berdasarkan nilai koefisien regresi dapat lihat pada Tabel 6, disusun model persamaan regresi sebagai berikut:

$$
Y=-3,686+0,104 X_{1}+0,122 X_{2}+0,129 X_{3}+0,091 X_{4}
$$

Interpretasi persamaan regresi liner berganda diatas adalah sebagai berikut:

$\mathrm{a}=$ Persamaan model matematika menunjukkan bahwa variabel Y sebagai variabel yang menunjukkan peningkatan biaya konstruksi sangat dipengaruhi, oleh variabel $\mathrm{X}_{1} \quad$ (Bekisting), variabel $\mathrm{X}_{2}$ (Pembesian), $\mathrm{X}_{3}$ (Pengecoran), dan variabel $\mathrm{X}_{4}$ (Pembongkaran Bekisting). "trend" atas persepsi responden, terhadap pada pernyataan yang ada 
dalam penelitian ini. Trend ini menunjukkan kearah positif dimulai dengan angkat konstan sebesa -3,686.

$\mathrm{B} 1=$ Nilai koefisien regresi variabel $\mathrm{X}_{1}$ (Bekisting) adalah 0,104 . Hasil ini merupakan menunjukan bahwa bekisting berpengaruh positif terhadap peningkatan biaya, yaitu semakin meningkatnya sisa material kesalahan yang dilakukan pekerja dalam pemotongan, mengggunakan meteriel triplek dengan kualitas rendah, pemotongan sisa bekisting bondek tidak digunakan, pengawasan pemesangan kurang intensif, Maka akan memberikan pengaruh positif terhadap peningkatan biaya konstruksi gedung bertingkat rendah

$\mathrm{B} 2=$ Nilai koefisien regresi variabel $\mathrm{X} 1$ (Bekisting) adalah 0,104 . Hasil ini memiliki berpengaruh positif terhadap peningkatan biaya yang ditunjukan trend grafik yang naik. Artinya jika variabel independen pembesian memiliki temuan bahwa sisa material besi yang terlanjur terpotong tidak sesuai ukuran, sisa pemotongan tidak digunakan, metode pemesangan yang kurang tepat, material berkarat akibat terlalu lama disimpan, Maka memberikan pengaruh positif terhadap peningkatan biaya konstruksi gedung bertingkat rendah

$\mathrm{B} 3=$ Nilai koefisien regresi variabel $\mathrm{X}_{3}$ (Pengecoran) adalah 0,129 , Hasil ini memiliki berpengaruh positif terhadap peningkatan biaya yang ditunjukan trend grafik yang naik. Artinya jika variabel independen pengecoran memiliki temuan bahwa sisa material semen pasir dan kerikil tercecer terbuang selama pembuatan adukan beton, kelebihan adukan beton dilapangan, ukuran batu split tidak sesuai spesifikasi, tidak merencanakan menggunakan material dengan baik., Maka akan memberikan pengaruh positif terhadap peningkatan biaya konstruksi gedung bertingkat rendah

B4 $=$ Nilai koefisien regresi variabel X4 (Pembongkaran Bekisting) adalah 0,091, Hasil ini memiliki berpengaruh positif terhadap peningkatan biaya yang ditunjukan trend grafik yang naik. Artinya Jika variabel independen pembongkaran bekisting memiliki temuan bahwa sisa material kayu dan triplek tidak awet untuk dipakai berulang-ulang kali, sisa potongan bondek tidak dapat di pakai lagi, paku dan kawat bendrat yang sudah tidak bisa dipakai kembali karena proses pemakaian, metode pembongkaran yang kurang tepat, Maka akan memberikan pengaruh positif terhadap peningkatan biaya konstruksi gedung bertingkat rendah
Gambaran korelasi menjelaskan keterkaitan dan hubungan diantara variabel $\mathrm{Y}$ dan $\mathrm{X}$ atau terkait ini hubungan yang erat pada variabel bekisting, pembesian, pengecoran, pembongkaran bekisting dengan variabel peningkatan biaya.

Tabel 7. Uji Korelasi Determinasi R Square

\begin{tabular}{ccccc}
\hline Model & $\mathrm{R}$ & $\begin{array}{c}\mathrm{R} \\
\text { Square }\end{array}$ & $\begin{array}{c}\text { Adjusted R } \\
\text { Square }\end{array}$ & $\begin{array}{c}\text { Std. Error of the } \\
\text { Estimate }\end{array}$ \\
\hline 1 & $.890^{\mathrm{a}}$ & .793 & .782 & .484 \\
\hline
\end{tabular}

Berdasarkan output pengolahan data, dapat dilihat pada point multiple dengan Nilai korelasi sebesar 0,890 tersebut membuktikan bahwa hubungan antara bekisting (X1), pembesian (X2), pengecoran (X3), pembongkaran bekisting (X4), dengan variabel peningkatan biaya yang secara signifikan dan kuat atau dinyatakan dengan $\mathrm{R}$ yang hasilnya mendekati +1 .

\section{R Square (Koefisien Determinasi)}

Perhitungan statistik yang memiliki variabel bebas lebih dari 2, maka akan lebih baik apabila menggunakan Adjusted $R$ Square. Hasil output statistik regresi liner berganda dalam riset ini memperoleh hasil sebanyak 0,782 dari hasil ini telah menjelaskan adanya kontribusi yang telah diberikan pada variabel bekisting (X1), pembesian (X2), pengecoran (X3), pembongkaran bekisting (X4) terhadap variabel peningkatan biaya dengan jumlah $78,2 \%$ dan sisanya sebesar $21,8 \%$ mendapatkan pengaruh dari beberapa faktor yang lainnya dan tidak termasuk pada riset yang dijalankan.

\section{Pengujian Hipotesis}

a. Uji T

Hipotesis untuk kasus pengujian $\mathrm{t}$ Tes adalah:

$\mathrm{H}_{\mathrm{O}} \quad: \mathrm{b}_{\mathrm{y} 1}=0$, tidak mempunyai pengaruh pada variabel $\mathrm{X}_{1}$ dengan variabel jenis $\mathrm{Y}$.

$\mathrm{H}_{1}: \mathrm{b}_{\mathrm{y} 1} \neq 0$, terdapat pengaruh dari 2 variabel yaitu $\mathrm{X}_{1}$ dan $\mathrm{Y}$.

$\mathrm{H}_{\mathrm{O}}: \mathrm{b}_{\mathrm{y} 2}=0$, tidak memiliki pengaruh dari variabel $\mathrm{X}_{2}$ pada variabel $\mathrm{Y}$.

$\mathrm{H}_{1}: \mathrm{b}_{\mathrm{y} 2} \neq 0$, adanya pengaruh dari 2 variabel $\left(\mathrm{X}_{2}\right.$ dan $\mathrm{Y})$.

$\mathrm{H}_{\mathrm{O}}: \mathrm{b}_{\mathrm{y} 3}=0$, tidak mempengaruhi variabel $\mathrm{X}_{3}$ pada variabel $\mathrm{Y}$

$H_{1}: b_{y 3} \neq 0$, antara $X_{3}$ dengan $Y$ ada pengaruh satu sama lain.

$\mathrm{H}_{\mathrm{O}}: \mathrm{b}_{\mathrm{y} 4}=0$, variabel $\mathrm{X} 4$ dengan variabel $\mathrm{Y}$ tidak terdapat pengaruh dari keduanya.

$\mathrm{H}_{1} \quad: b_{\mathrm{y} 4} \neq 0$, variabel $\mathrm{X}_{4}$ dengan variabel $\mathrm{Y}$ terdapat pengaruh keduanya. 
Jumlah signifikansi sebanyak 5\% $(\alpha=0,05)$

Degree of freedom $(\mathrm{df})=(\mathrm{n}-\mathrm{p}-1)$

Keterangannya adalah $\mathrm{n}$ merupakan jumlah data, $\mathrm{p}$ yaitu jumlah dari variabel bebas atau $\mathrm{X}$ sehingga hasil dari $(\mathrm{df})=$ 84-4-1 = 79 dan hasil pada $\mathrm{t}_{(0,05: 79)}$ pada $\mathrm{t}_{\text {Tabel }}$ mendapatkan angka sejumlah 1,99.

Berdasarkan Tabel 8 dapat dilihat nilai variabel bekisting hasilnya sejumlah 2,245 yang dinyatakan lebih besar dari tabel yaitu sebesar 1,99, variabel pembesian mempunyai hasil sebanyak 2,137 yang hasilnya lebih besar juga dari $t_{\text {tabel }}$ sejumlah 1,99 , variabel pada pengecoran yang berjumlah 2,223 yang nilainya lebih besar dibandingkan $t_{\text {tabel }}$ 1,99, dan variabel pembongkaran bekisting sebesar 2,031 yang hasilnya lebih besar dari tabel 1,99. Maka dapat disimpulkan dari 4 variabel tersebut memiliki pengaruh pada meningkatnya biaya konstruksi secara sigfinikan.

Setelah mengetahui hasil yang telah disajikan dalam tabel maka dapat dilihat bahwa dari keempat variabel dinyatakan paling dominan mempunyai pengaruh pada peningkatan biaya konstruksi yaitu pada variabel pekerjaan bekisting. Dalam hal ini berarti sisa material (waste) untuk variabel pekerjaan bekisting lebih banyak dibandingkan dengan variabel lain.

\section{b. Uji F}

Dalam menguji dari kedua variabel bebas $\mathrm{X}$ yang dilakukan secara bersama pada variabel $\mathrm{Y}$ dengan menggunakan uji F, yakni menerapkan prosedur diantaranya:

1) Menentukan dengan Hipotesis:

hipotesis yang digunkan pada kasus pengajuan F-tes yaitu:

Ho $b_{y 1234}=0$, mempunyai makna tidak adanya pengaruh dari variabel $\mathrm{X}$ pada variabel $\mathrm{Y}$ secara bersamaan.

$\mathrm{H}_{1} \mathrm{~b}_{\mathrm{y} 1234} \neq 0$, dapat diartikan dengan variabel $\mathrm{X}$ dengan variabel Y secara bersama-sama mempunyai pengaruh.

2) Penentuan menggunakan $F_{\text {tabel }}$ dan $F_{\text {hitung }}$

sifnifikansi mempunyai tingkatan sebanyak 5\% $(\alpha=$ $0,05)$ degree of freedom: adalah hasil output SPSS pada bagian di Annova dan kolom df: mendapatkan numerator sejumlah 4 dan denumator sebanyak 79, sehingga $\mathrm{F}_{\text {tabel }}$ untuk $\mathrm{F}_{(0,05: 4: 79)}$ didapat $+2,487$.

Tabel 9. Uji F

\begin{tabular}{lccccc}
\hline \multicolumn{1}{c}{ Model } & $\begin{array}{c}\text { Sum of } \\
\text { Squares }\end{array}$ & df & $\begin{array}{c}\text { Mean } \\
\text { Square }\end{array}$ & F & Sig. \\
\hline Regression & 70.729 & 4 & 17.682 & 75.472 & $.000^{\mathrm{a}}$ \\
Residual & 18.509 & 79 & .234 & & \\
Total & 89.238 & 83 & & & \\
\hline
\end{tabular}

Berdasarkan hasil Uji F menggunakan aplikasi SPSS pada Tabel 9 dalam kolom $F$ mendapatkan $F_{\text {hitung }}$ sebanyak 75,472. Apabila $F_{\text {hitung }}$ lebih besar dari $F_{\text {tabel, maka }}$ pernyataanya adalah $\mathrm{H}_{0}$ ditolak Bila $\mathrm{F}_{\text {hitungnya lebih kecil }}$ dari $\mathrm{F}_{\text {tabel}}$, maka kesimpulannya adalah Ho dinyatakan diterima Pada tabel tersebut didapatkan $F_{\text {hitung }}$ dengan jumlah 75,472 yang nilainya lebih besar daripada $F_{\text {tabel }}$ sebesar 2,487, sehingga $\mathrm{H}_{0}$ dinyatakan dengan ditolak atau $\mathrm{H}_{1}$ dikatakan diterima, artinya variabel pembesian, bekisting, pengecoran serta pembongkaran bekisting secara bersamasama berpengaruh terhadap peningkatan biaya konstruksi

\section{Pembahasan Hasil Penelitian}

Berdasarkan hasil analisis berikut ini akan dibahas mengenai hasil penelitian dan diinterpretasikan sebagai berikut:

- Berdasarkan analisis statistik deskriptif, indikator yang memiliki skor tertinggi yaitu pada Variabel Pekerjaan Bekisting untuk indikator X1.4 dan Pekerjaan Pembongkaran Bekisting untuk indikator X4.4 yaitu "Pengawasan pemasangan bekisting kurang intensif" dan "Metode pembongkaran yang kurang tepat" dengan skor total 341 dan rata-rata 4.059, hal ini menyimpulkan bahwa berdasarkan analisis statistik deskriptif, pengaruh sisa material paling dominan yang menyebabkan terhadap peningkatan biaya konstruksi gedung bertingkat rendah di Jakarta adalah pekerjaan bekisting dan pekerjaan pembongkaran bekisting.

- Uji Reliabilitas digunakan untuk mengetahui konsistensi alat ukur, apakah alat pengukur yang digunakan dapat diandalkan dan tetap konsisten jika pengukuran tersebut diulang. Dari hasil uji reliabilitas didapat nilai Cronbach's Alpha sebesar rata-rata lebih dari nilai $\mathrm{r}$ tabel pada pengujian validitas $>0.444$. Maka dapat disimpulkan bahwa instrumen dalam penelitian ini reliabel atau konsisten.

- Uji Reliabilitas digunakan untuk mengetahui konsistensi alat ukur, apakah alat pengukur yang digunakan dapat diandalkan dan tetap konsisten jika pengukuran tersebut diulang. Dari hasil uji reliabilitas didapat nilai Cronbach's Alpha sebesar rata-rata lebih dari nilaii $\mathrm{r}$ tabel pada hasil perhitungan diperoleh bahwa semua variabel memiliki nilai koefisien reliabilitas $(r)>0,60$ dengan demikian semua variabel penelitian dapat dikatakan memiliki status yang reliabel.

- Uji multikolinearitas adalah suatu keadaan dimana antar variabel X (bebas) saling berkorelasi satu dengan yang lainnya. Berdasarkan tabel hasil pada bagian Coefficient dapat dilihat ketiga variabel independen, angka VIF ada di bawah $10\left(X_{1}=3,781, X_{2}=5,943, X_{3}=5,348\right.$ dan $X_{4}$ 
$=3,735)$. Demikian juga nilai tolerance berada di atas $0,10\left(\mathrm{X}_{1}=0,265, \mathrm{X}_{2}=0,168, \mathrm{X}_{4}=0,187\right.$ dan $\mathrm{X}_{4}=$ $0,268)$. Disimpulkan bahwa model regresi tersebut tidak terdapat problem multikolinieritas baik berdasarkan pada besaran VIF maupun besaran korelasi antar variabel.

- Uji Heterokedastisitas tujuannya adalah untuk menguji apakah dalam sebuah model regresi, terjadi ketidaksamaan varians dari residual dari satu pengamatan ke pengamatan yang lain. Berdasarkan hasil yang didapat, terlihat titik-titik menyebar secara acak, tidak membentuk sebuah pola tertentu yang jelas, serta tersebar baik di atas maupun di bawah angka 0 pada sumbu Y. Hal ini berarti tidak terjadi heteroskedastisitas pada model regresi.

- Uji Normalitas bertujuan untuk mengetahui apakah nilai residual berdistribusi normal atau tidak. Model regresi yang baik adalah memiliki residual yang berdistribusi normal.

- Dasar pengambilan keputusan Jika data menyebar di sekitar garis diagonal dan mengikuti arah garis diagonal, maka model regresi memenuhi asumsi normalitas.

- Jika data menyebar jauh dari garis diagonal dan/atau tidak mengikuti arah garis diagonal, maka model regresi tidak memenuhi asumsi normalitas.

- Berdasarkan hasil uji normalitas diketahui terlihat titiktitik menyebar di sekitar garis diagonal, serta penyebarannya mengikuti arah garis diagonal. Maka dapat disimpulkan model regresi ini memenuhi asumsi normalitas.

- Analisis Regresi Linier Berganda bertujuan untuk mengetahui arah hubungan antara variabel independen dengan variabel dependen apakah masing-masing variabel independen berhubungan positif atau negatif dan untuk memprediksi nilai dari variabel dependen apabila nilai variabel independen mengalami kenaikan atau penurunan.

Persamaan regresi linier berganda sebagai berikut:

$\mathrm{a}=$ Persamaan model matematika menunjukkan bahwa variabel $\mathrm{Y}$ sebagai variabel yang menunjukkan peningkatan biaya konstruksi sangat dipengaruhi, oleh variabel $\mathrm{X}_{1}$ (Bekisting), variabel $\mathrm{X}_{2}$ (Pembesian), $\mathrm{X}_{3}$ (Pengecoran), dan variabel $\mathrm{X}_{4}$ (Pembongkaran Bekisting). "trend" atas persepsi responden, terhadap pada pernyataan yang ada dalam penelitian ini. Trend ini menunjukkan kearah positif dimulai dengan angkat konstan sebesar $-3,686$.

$\mathrm{B} 1=$ Nilai koefisien regresi variabel $\mathrm{X}_{1}$ (Bekisting) adalah 0,104. Hasil ini memiliki berpengaruh positif terhadap peningkatan biaya yang ditunjukkan trend grafik yang naik. Artinya jika variabel independen bekisting memiliki temuan bahwa sisa material kesalahan yang dilakukan pekerja dalam pemotongan, mengggunakan meteriel triplek dengan kualitas rendah, pemotongan sisa bekisting bondek tidak digunakan, pengawasan pemesangan kurang intensif, Maka akan memberikan pengaruh positif terhadap peningkatan biaya konstruksi gedung bertingkat rendah

$\mathrm{B} 2$ = Nilai koefisien regresi variabel $\mathrm{X}_{2}$ (Pembesian) adalah 0,122, Hasil ini memiliki berpengaruh positif terhadap peningkatan biaya yang ditunjukan trend grafik yang naik. Artinya jika variabel independen pembesian memiliki temuan bahwa sisa material besi yang terlanjur terpotong tidak sesuai ukuran, sisa pemotongan tidak digunakan, metode pemesangan yang kurang tepat, material berkarat akibat terlalu lama disimpan, Maka memberikan pengaruh positif terhadap peningkatan biaya konstruksi gedung bertingkat rendah

$\mathrm{B} 3=$ Nilai koefisien regresi variabel $\mathrm{X}_{3}$ (Pengecoran) adalah 0,129. Hasil ini memiliki berpengaruh positif terhadap peningkatan biaya yang ditunjukan trend grafik yang naik. Artinya jika variabel independen pengecoran memiliki temuan bahwa sisa material semen pasir dan kerikil tercecer terbuang selama pembuatan adukan beton, kelebihan adukan beton dilapangan, ukuran batu split tidak sesuai spesifikasi, tidak merencanakan menggunakan material dengan baik., Maka akan memberikan pengaruh positif terhadap peningkatan biaya konstruksi gedung bertingkat rendah

B4 = Nilai koefisien regresi variabel X4 (Pembongkaran Bekisting) adalah 0,091. Hasil ini memiliki berpengaruh positif terhadap peningkatan biaya yang ditunjukan trend grafik yang naik. Artinya Jika variabel independen pembongkaran bekisting memiliki temuan bahwa sisa material kayu dan triplek tidak awet untuk dipakai berulang-ulang kali, sisa potongan bondek tidak dapat di pakai lagi, paku dan kawat bendrat yang sudah tidak bisa dipakai kembali karena proses pemakaian, metode pembongkaran yang kurang tepat, Maka akan memberikan pengaruh positif terhadap peningkatan biaya konstruksi gedung bertingkat rendah 
- Uji T dilakukan dengan tujuan apakah variabel bebas secara parsial mempengaruhi peningkatan biaya konstruksi. Penentuan hasil uji F dapat dilihat jika

Jika $t_{\text {hitung }}>t_{\text {tabel}}$, maka Ho tolak

Jika $t_{\text {hitung }}<\mathrm{t}_{\text {tabel }}$, maka Ho diterima

Berdasarkan hasil uji $\mathrm{t}$ diperoleh pekerjaan bekisting sebesar 2,245, pembesian sebesar 2,137, pengecoran sebesar 2,223 dan pembongkaran bekisting sebesar 2,031. Variabel yang paling dominan mempengaruhi peningkatan biaya konstruksi adalah variabel pekerjaan bekisting.

- Uji F dilakukan dengan tujuan apakah variabel bebas secara bersama-sama mempengaruhi peningkatan biaya konstruksi

Ho $b_{\mathrm{y} 1234}=0$, artinya tidak ada pengaruh variabel $\mathrm{X}$ secara bersama-sama terhadap variabel $\mathrm{Y}$.

$\mathrm{H}_{1} \mathrm{~b}_{\mathrm{y} 1234} \neq 0$, artinya ada pengaruh variabel $\mathrm{X}$ secara bersama-sama terhadap variabel $\mathrm{Y}$.

Hasil dari uji $F$ yaitu $F_{\text {hitung }}(75,472)$ jauh lebih besar dari $\mathrm{F}_{\text {tabel }}(2,487)$, maka Ho ditolak atau $\mathrm{H}_{1}$ diterima, berarti variabel bekisting, pembesian, pengecoran dan pembongkaran bekisting secara bersama-sama berpengaruh terhadap peningkatan biaya konstruksi.

- Sisa material (waste) dari pekerjaan struktur gedung bertingkat rendah yang memiliki dampak peningkatan biaya di proyek konstruksi gedung bertingkat rendah di Jakarta terdiri dari pekerjaan bekisting, pekerjaan pembesian, pekerjaan pengecoran dan pekerjaan pembongkaran bekisting.

- Sisa material (waste) dari pekerjaan bekisting disebabkan oleh kesalahan yang dilakukan pekerja dalam pemotongan kayu, menggunakan material triplek dengan kualitas rendah, pemotongan sisa bekisting bondek tidak digunakan, pengawasan pemasangan bekisting kurang intensif.

- Sisa material (waste) dari pekerjaan pembesian disebabkan oleh besi yang terlanjur terpotong tidak sesuai ukuran, sisa pemotongan tidak dapat digunakan, metode pemasangan yang kurang tepat, material berkarat akibat terlalu lama disimpan.

- Sisa material (waste) dari pekerjaan pengecoran disebabkan oleh material semen, pasir dan kerikil tercecer, tebuang selama pembuatan adukan beton, kelebihan adukan beton dilapangan, ukuran batu split yang tidak sesuai spesifikasi, serta tidak merencanakan menggunakan material dengan baik.

- Sisa material (waste) dari pekerjaan pembongkaran bekisting disebabkan oleh material kayu dan triplek tidak awet untuk dipakai berulang-ulang kali, sisa potongan bekisting bondek tidak daapat dipakai lagi, paku dan kawat bendrat yang sudah tidak bisa dipakai kembali karena proses pemakaian dan metode pembongkaran yang kurang tepat (sesuai yg terjadi di lapangan).

Hasil penelitian ini mendukung penelitian yang dilakukan oleh K. Liman, dkk [1], I Putu Gusti, dkk [9], yang menyatakan bahwa sisa material (waste) sering terjadi pada pekerjaan bekisting, pekerjaan pembesian sehingga mempengaruhi peningkatan biaya proyek.

Hasil penelitian ini mendukung penelitian yang dilakukan oleh Pertiwi, dkk [10] menyatakan bahwa sisa material yang dominan mempengaruhi peningkatan biaya adalah pekerjaan pembesian.

Hasil penelitian ini mendukung penelitian yang dilakukan oleh T. James, dkk [8] menyatakan bahwa sisa material proyek dapat meningkatkan biaya proyek.

\section{Simpulan}

Berdasarkan hasil hasil analisis dan pembahasan dapat disimpulkan sebagai berikut:

a. Sisa material (waste) dari pekerjaan struktur gedung bertingkat rendah yang memiliki dampak peningkatan biaya di proyek konstruksi gedung bertingkat rendah di Jakarta yaitu dari pekerjaan bekisting, pekerjaan pembesian, pekerjaan pengecoran dan pekerjaan pembongkaran bekisting.

b. Variabel bekisting, pembesian, pengecoran dan pembongkaran bekisting berpengaruh terhadap persentase peningkatan biaya konstruksi. Sedangkan variabel yang paling dominan mempengaruhi peningkatan biaya konstruksi adalah variabel pekerjaan bekisting.

c. Peningkatan biaya konstruksi diperoleh dari indikator yang memiliki skor tertinggi yaitu pada tabel Pekerjaan Bekisting untuk indikator X1.4 dengan persentase 0,94 \% dan Pekerjaan Pembongkaran Bekisting untuk indikator X4.4 dengan persentase $0,97 \%$ yaitu "Pengawasan pemasangan bekisting kurang intensif" dan "Metode pembongkaran yang kurang tepat" dengan skor total 341 dan rata-rata 4.059, hal ini menyimpulkan bahwa berdasarkan analisis statistik deskriptif, pengaruh sisa material paling dominan yang menyebabkan terhadap peningkatan biaya konstruksi gedung bertingkat rendah di Jakarta adalah Pekerjaan Bekisting dan Pekerjaan Pembongkaran Bekisting. Hal ini berarti peningkatan biaya konstruksi termasuk dalam kategori yang baik sekali. Hal ini berarti peningkatan biaya konstruksi termasuk dalam kategori yang masih baik. Pernyataan ini didukung oleh hasil pengujian analisis regresi berganda, berdasarkan hasil pengujian tersebut nilai koefisien regresi positif (yang di tunjukan dengan nilai beta sebesar $(B)=0.201)$ 


\section{Daftar Pustaka}

[1] Kelvin Liman., dan Hendrik Sulistio "Waste Material Beton pada Proyek Konstruksi di Jakarta”. JMFS: Jurnal Mira Teknik Sipil vol. 3, no. 1, pp. 183-190, 2020.

[2] Suryanto Intan "Analisa dan evaluasi sisa material konstruksi pada pembangunan ruko di Surabaya". PhDThesis. Petra Christian University, 2014.

[3] Yatnanta Padma Devia., Saifoe El Unas.,dan W, Nariswari."Identifikasi Sisa Material Konstruksi dalam upaya memenuhi bangunan berkelanjutan". Rekayasa Sipil vol. 4 no. 3. pp. 195-203, 2012.

[4] Novinda Anisa Aulia., Harimurti., dan Kartika Puspa Negara,"Analisis dan Evaluasi Sisa Material Konstruksi Menggunakan. Metode Pareto dan Fishbone Diagram (Studi Kasus pada Proyek Pembangunan Gedung Pascasarjana Universitas Islam Malang)". Jurnal Mahasiswa Jurusan Teknik Sipil, vol. 1. no. 2, p. PP-649, 2016.

[5] Hanif Nursyahbani., Kartika Puspa Negara.,dan Achfas Zacoeb "Analisis dan Evaluasi Sisa Material Konstruksi Menggunakan Fault Tree Analysis (FTA) (Studi Kasus pada Proyek Pembangunan Gedung Pascasarjana Universitas Islam Malang)". Jurnal Mahasiswa Jurusan Teknik Sipil, vol 1. no. 2. p. PP641. 2016.

[6] Widi Hartono., Sugiyarto., daan Sukho Baskoro.
"Analisis Dan Identifikasi Sisa Material Konstruksi Pembangunan Gedung Kantor Dan Rumah Dinas Kelurahan Gilingan (Studi Kasus Gedung Kelurahan Dan Rumah Dinas Kelurahan Gilingan)". Matriks Teknik Sipil. vol. 4. no. 1, 2016.

[7] Zulkibli., Nawir Rasidi., dan Andi Kristafi Arifianto. "Hubungan Antara Pengelolaan, Pengendalian Sisa Material Dengan Biaya Dan Waktu Penyelesaian Pembangunan Gedung PSIK Di Universitas Tribhuwana Tunggadewi Malang”. eUREKA: Jurnal Penelitian Teknik Sipil dan Teknik Kimia., vol. 1, no. 2. 2017.

[8] James Thoengsal."Efisiensi Penggunaan Material Konstruksi Dalam Mereduksi Timbulnya Material Sisa(WasteMaterial)".http://jamesthoengsal.blogspot .co.id/p/ blog-page_20.html, diakses 2021.

[9] I Gusti Putu Adi Suartika Putra., G A P Chandra Dharmayanti dan A.A.Diah Parami Dewi. "Penanganan Waste Material Pada Proyek Konstruksi Gedung Bertingkat ". Jurnal Spektran, vol. 6, no. 2, Hal. 133 - 262, Juli 2018.

[10] Igai Mas Pertiwi., Fajar Surya Herlambang., dan Wayan Sri Kristinayati. "Analisis Waste Material Konstruksi Pda Proyek Gedung (Studi Kasus Pada Proyek Gedung Di Kabupaten Badung)".Jurnal Simetrik, vol.9, No.1, Juni 2019.

Tabel 3. Hasil Analisis Deskriptif

\begin{tabular}{|c|c|c|c|c|c|c|c|c|c|}
\hline & $\mathrm{N}$ & Range & Minimum & Maximum & Sum & \multicolumn{2}{|c|}{ Mean } & Std. Deviation & Variance \\
\hline & Statistic & Statistic & Statistic & Statistic & Statistic & Statistic & Std. Error & Statistic & Statistic \\
\hline Responden & 84 & 83 & 1.00 & 84 & 3570 & 42.50 & 2.661 & 24.393 & 595.000 \\
\hline $\mathrm{X} 1.1$ & 84 & 3.00 & 2.00 & 5.00 & 314.00 & 3.7381 & .07783 & .71337 & .509 \\
\hline $\mathrm{X} 1.2$ & 84 & 3.00 & 2.00 & 5.00 & 317.00 & 3.7738 & .08358 & .76601 & .587 \\
\hline $\mathrm{X} 1.3$ & 84 & 3.00 & 2.00 & 5.00 & 312.00 & 3.7143 & .09365 & .85829 & .737 \\
\hline $\mathrm{X} 1.4$ & 84 & 4.00 & 1.00 & 5.00 & 332.00 & 3.9524 & .07364 & .67493 & .456 \\
\hline $\mathrm{X} 2.1$ & 84 & 3.00 & 2.00 & 5.00 & 326.00 & 3.8810 & .07651 & .70120 & .492 \\
\hline $\mathrm{X} 2.2$ & 84 & 4.00 & 1.00 & 5.00 & 337.00 & 4.0119 & .08881 & .81395 & .663 \\
\hline $\mathrm{X} 2.3$ & 84 & 3.00 & 2.00 & 5.00 & 337.00 & 4.0119 & .07852 & .71967 & .518 \\
\hline $\mathrm{X} 2.4$ & 84 & 3.00 & 2.00 & 5.00 & 318.00 & 3.7857 & .08135 & .74561 & .556 \\
\hline X3.1 & 84 & 3.00 & 2.00 & 5.00 & 319.00 & 3.7976 & .08084 & .74088 & .549 \\
\hline X3.2 & 84 & 3.00 & 2.00 & 5.00 & 331.00 & 3.9405 & .07641 & .70028 & .490 \\
\hline X3.3 & 84 & 3.00 & 2.00 & 5.00 & 325.00 & 3.8690 & .08431 & .77272 & .597 \\
\hline X3.4 & 84 & 4.00 & 1.00 & 5.00 & 319.00 & 3.7976 & .08600 & .78816 & .621 \\
\hline $\mathrm{X} 4.1$ & 84 & 3.00 & 2.00 & 5.00 & 327.00 & 3.8929 & .08300 & .76075 & .579 \\
\hline $\mathrm{X} 4.2$ & 84 & 4.00 & 1.00 & 5.00 & 324.00 & 3.8571 & .08985 & .82349 & .678 \\
\hline $\mathrm{X} 4.3$ & 84 & 3.00 & 2.00 & 5.00 & 341.00 & 4.0595 & .07826 & .71728 & .514 \\
\hline X4.4 & 84 & 3.00 & 2.00 & 5.00 & 341.00 & 4.0595 & .07641 & .70028 & .490 \\
\hline $\begin{array}{c}\text { Valid N } \\
\text { (listwise) }\end{array}$ & 84 & & & & & & & & \\
\hline
\end{tabular}


Tabel 6. Uji Regresi Linier Berganda

\begin{tabular}{|c|c|c|c|c|c|c|}
\hline & \multirow{2}{*}{ Model } & \multicolumn{2}{|c|}{$\begin{array}{l}\text { Unstandardized } \\
\text { Coefficients }\end{array}$} & \multirow{2}{*}{$\begin{array}{c}\begin{array}{c}\text { Standardized } \\
\text { Coefficients }\end{array} \\
\text { Beta }\end{array}$} & \multirow[t]{2}{*}{$\mathrm{t}$} & \multirow{2}{*}{ Sig. } \\
\hline & & B & Std. Error & & & \\
\hline \multirow{5}{*}{1} & (Constant) & -3.686 & .405 & & -9106 & .000 \\
\hline & Bekisting (X1) & .104 & .046 & .224 & 2.245 & .028 \\
\hline & Pembesian (X2) & .122 & .057 & .267 & 2.137 & .036 \\
\hline & Pengecoran (X3) & .129 & .058 & .263 & 2.223 & .029 \\
\hline & Pembongkaran Bekisting (X4) & .091 & .045 & .201 & 2.031 & .046 \\
\hline
\end{tabular}

Tabel 8. Uji T

\begin{tabular}{|c|c|c|c|c|c|c|}
\hline & \multirow[t]{2}{*}{ Model } & \multicolumn{2}{|c|}{$\begin{array}{c}\text { Unstandardized } \\
\text { Coefficients }\end{array}$} & \multirow{2}{*}{$\begin{array}{c}\text { Standardized } \\
\text { Coefficients }\end{array}$} & \multirow[t]{2}{*}{$\mathrm{t}$} & \multirow[t]{2}{*}{ Sig. } \\
\hline & & $\mathrm{B}$ & Std. Error & & & \\
\hline \multirow{5}{*}{1} & (Constant) & -3.686 & .405 & & -9.106 & .000 \\
\hline & Bekisting (X1) & .104 & .046 & .224 & 2.245 & .028 \\
\hline & Pembesian (X2) & .122 & .057 & .267 & 2.137 & .036 \\
\hline & Pengecoran (X3) & .129 & .058 & .263 & 2.223 & .029 \\
\hline & Pembongkaran Bekisting (X4) & .091 & .045 & .201 & 2.031 & .046 \\
\hline
\end{tabular}

